\title{
Spatial aggregations of seabirds and their prey on the continental shelf off SW Vancouver Island
}

\author{
Alan E. Burger ${ }^{1, *}$, Christine L. Hitchcock ${ }^{2}$, Gail K. Davoren ${ }^{3,4}$ \\ ${ }^{1}$ Department of Biology, University of Victoria, Victoria, British Columbia V8W 3N5, Canada \\ ${ }^{2}$ Department of Medicine, Division of Endocrinology, \#380-575 W 8th Ave, Vancouver, British Columbia V5Z 1C6, Canada \\ ${ }^{3}$ Cognitive and Behavioural Ecology Programme, Departments of Biology and Psychology, Memorial University, St John's, \\ Newfoundland A1B 3X9, Canada
}

${ }^{4}$ Present address: Department of Zoology, University of Manitoba, Winnipeg, Manitoba R3T 2N2, Canada

\begin{abstract}
We investigated the spatial scales at which seabirds aggregate and associate with prey over the continental shelf off southwest Vancouver Island, British Columbia. Bird densities and hydroacoustic measures of prey abundance were recorded in all seasons from 1993 to 1995 from a vessel moving along fixed strip transects (mean distance $93 \mathrm{~km}$; minimum spatial units $250 \mathrm{~m}$ ). We used the neighbour $\mathrm{K}$ analysis to determine the spatial scale (patch radius) and number of birds (crowding) associated with aggregations of birds. Birds were grouped into 3 guilds: divers (dominated by common murres Uria aalge and other alcids), surface-feeders (dominated by California gulls Larus californicus and other gulls) and shearwaters (mainly sooty shearwaters Puffinus griseus). Flying birds occurred in smaller aggregations spread over a wider area than birds on the water. For birds on the water, patch radii were usually 2 to $8 \mathrm{~km}$, and crowding averaged 574, 143 and 50 birds per patch for surface-feeders, shearwaters and divers, respectively. Patch radii showed few significant differences among bird species and guilds, and remained relatively constant throughout the year for most species, despite large seasonal changes in density and mean crowding. Abundance of prey (small schooling fish and euphausiids) was highest in the upper $10 \mathrm{~m}$, declining progressively with deeper depths and showed marked seasonal trends (mean scores 4 to $5 \times$ higher in summer than in winter). Significant associations between birds and prey were usually within patch radii of 2 to $8 \mathrm{~km}$. The appropriate scale to map and monitor seabirds and seabird-prey associations, for oil spill assessments and other reasons, would therefore be 1 to $10 \mathrm{~km}$.
\end{abstract}

KEY WORDS: Spatial distribution · Seabirds · Predator-prey interactions · Scale · Vancouver Island · Continental shelf $\cdot$ Foraging guilds

\section{INTRODUCTION}

Describing the density and spatial distribution of seabirds is an important step in understanding their role in marine ecosystems and their vulnerability to changes in these ecosystems (Hunt et al. 1999). In particular, this information is essential for understanding the birds' responses to variability in physical and biological marine processes (Hunt \& Schneider 1987), and assessing likely impacts and risks to seabirds from oil spills, other chemical contamination, over-fishing of prey and accidental by-catch in fishing gear (Wiens et al. 1984, Montevecchi 2002). We report year-round measures of density and spatial aggregation of seabirds over the inner continental shelf off southwest Vancouver Island, British Columbia. We also report hydroacoustic measures and spatial aggregation of relative prey abundance, and the associations of seabirds with these prey patches. This information is critical for a broader understanding of how predators respond to distributions of epipelagic prey. This paper is part of an investigation into the diversity, abundance and distribution of seabirds in this productive area, and their vulnerability to oil spills and changes in the local ocean environment (Davoren \& Burger 1999, Davoren 2000, Burger 2003). 
Measures of spatial aggregation of seabirds and their relationships with prey are both highly sensitive to the scales at which these parameters are measured (Schneider \& Piatt 1986, Hunt \& Schneider 1987, Logerwell et al. 1998, O'Driscoll 1998, Davoren 2000, Davoren et al. 2002, 2003, Schneider 2002). Patterns and correlations which are evident at one spatial scale (e.g. $1 \mathrm{~km}$ along a linear transect) might become obscured or undetectable at smaller (100s m) or larger (10s km) scales (Fauchald et al. 2000). We report spatial scales at which common seabird species and trophic guilds off Vancouver Island aggregated, and at which the seabirds were associated with their potential prey.

Spatial patterns exhibit 2 distinct characteristics, defined as the grain and intensity (Pielou 1969, O'Driscoll 1998). Grain is the spatial distance between patches of high density, whereas intensity is the measure of grouping or crowding within these patches (O'Driscoll 1998). In our analysis we used the neighbour K statistical analysis, which provides measures of both grain and intensity for seabird distributions along transects, and also for the associations between the birds and their prey (O'Driscoll 1998, Davoren 2000, Davoren et al. 2002, 2003). This method has several advantages, reviewed by O'Driscoll (1998) and O'Driscoll et al. (2000), over earlier methods of determining spatial distributions of seabirds, such as variance:mean ratios, binning data in progressively larger sample units or spectral analysis. This is the first study to determine spatial aggregations and bird-prey aggregations for a complete community of seabirds throughout all seasons. Patterns revealed in our analysis are applicable to other epipelagic predators with similar foraging strategies and constraints in other marine ecosystems.

The waters of the continental shelf off southwest Vancouver Island support a productive marine ecosystem and a large and diverse avifauna (Martin \& Myres 1969, Vermeer et al. 1989, 1992, Morgan et al. 1991, Hay 1992, Wahl et al. 1993). About 300 laden oil tankers and thousands of other vessels transit this area annually, posing a real threat from catastrophic or chronic oil spills (Ford et al. 1991, Burger 1992, 1993a, 1993b, Anon. 2002). Our methods and results are useful for monitoring the year-round responses of birds to variations in ocean conditions, either anthropogenic (e.g. oil pollution and fishing) or climate-driven (e.g. El Niño, Pacific Decadal Oscillations, global climate change).

\section{MATERIALS AND METHODS}

Study area and survey methods. Birds and prey were simultaneously and continuously sampled along fixed transects over the continental shelf off southwest Vancouver Island (Fig. 1; Burger 2003). Most surveys followed a $120 \mathrm{~km}$ transect route encompassing the inner shelf region (Pachena and Inshelf legs), the edges of the Juan de Fuca marine canyon (Canyon leg), the outer shelf region (Offshelf leg) and a crossshelf transect back to Barkley Sound (Crosshelf leg). During winter when daylight was limiting, we reduced the survey by crossing the shelf diagonally from the outer Canyon end towards Cape Beale. Mechanical problems with the vessel also reduced the duration of 2 surveys. Surveys averaged $6.3 \mathrm{~h}( \pm 2.1 \mathrm{~h} \mathrm{SD}$; range 1.4 to 9.0 ; median $7.5 \mathrm{~h}$ ) and $93 \mathrm{~km}$ in length.

For all but 2 surveys, we used the $11 \mathrm{~m}$ research vessel MV 'Alta' (eye-level 2.0 to $2.5 \mathrm{~m}$ above the sea). Surveys in November and December 1995 used the $20 \mathrm{~m}$ trawler 'Dalewood Provider' (eye-level 3.0 to $3.5 \mathrm{~m}$ above sea level). Vessel speed was relatively constant (mean 8 knots $\left[14.8 \mathrm{~km} \mathrm{~h}^{-1}\right.$ ]; range 7 to 10 knots [13.0 to $18.5 \mathrm{~km} \mathrm{~h}^{-1}$ ]) but was occasionally slowed to identify birds in dense flocks. Surveys were usually restricted to periods with Beaufort sea state 3 or less (winds $<5.5 \mathrm{~m} \mathrm{~s}^{-1}$ and white-caps from breaking wavelets rare), although data were collected during brief periods of stronger winds to ensure continuity of the transects.

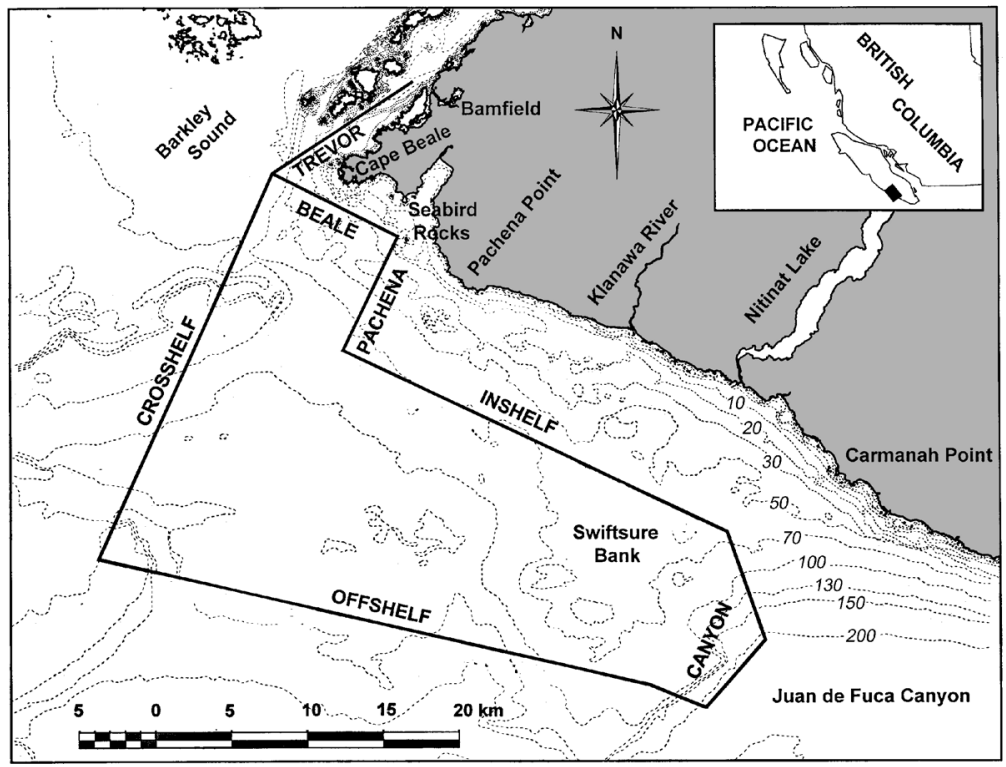

Fig. 1. Transect route used for seabird counts off southwest Vancouver Island. This paper includes data from the Pachena, Inshelf, Canyon, Offshelf and Crosshelf legs, but not the Trevor and Beale legs, which had different marine environments. Depth isobaths are in $\mathrm{m}$ 
Bird observations were made by 2 observers scanning forward $90^{\circ}$ horizontally on either side of the vessel and recorded in 1 min intervals (minimum spatial unit 250 to $280 \mathrm{~m}$ ). Several observers took turns on duty to avoid fatigue. We counted all birds within $150 \mathrm{~m}$ on either side of the vessel (i.e. $300 \mathrm{~m}$ wide strip). Observers were trained to estimate distances with reference to known distances measured with the ship's radar. Tests suggested that few birds were missed within $150 \mathrm{~m}$ but wider strips underestimated densities (A. E. Burger unpubl. data). Birds flying more than $250 \mathrm{~m}$ ahead of the vessel, following the vessel or crossing behind the vessel were not counted. Flying birds and those on the water were recorded separately. Our method of counting all flying birds transiting the observed area ahead of the vessel likely overestimated their densities (Tasker et al. 1984, Van Franeker 1994) but this error should be consistent within species and species-groups.

Prey abundance was measured using a hullmounted $200 \mathrm{kHz}$ Furuno 600 sounder with a paper recorder, which sampled the water below about $1 \mathrm{~m}$ depth. We divided the sounder traces into 1 min travel intervals (approx. $250 \mathrm{~m}$ ) and $10 \mathrm{~m}$ depth intervals (1 to $10 \mathrm{~m}$ for the surface water). Within each cell formed by these divisions, we visually scored the density of prey, based on the intensity of the sounder trace using a scale of 0 (no prey) through 9 (near-saturation; Piatt 1990). We then squared the score to account for the non-linear change in sounder intensity relative to prey school density (Forbes \& Nakken 1972). We focused on the 1 to $10 \mathrm{~m}$ depth range, as a measure of near-surface prey likely to be accessible to surface-feeding birds, and on the 1 to $40 \mathrm{~m}$ range, as a measure of the overall prey abundance accessible to most diving birds. Forty $m$ was selected as an appropriate depth setting for the sounder because this covered the typical foraging ranges of most diving birds (Burger 1991). Our surveys which sampled deeper depths showed few schools below $40 \mathrm{~m}$, except Pacific hake Merluccius productus (discussed below).

We did not directly identify the organisms producing each sounder trace, due to the range of nets needed to capture various prey types, the ability of many fish and euphausiids to evade nets, and other logistical problems (Logerwell \& Hargreaves 1996, Parrish et al. 1998). Instead, published material, opportunistic samples of near-surface fish and euphausiids, and analysis of birds' diets in this area were used to characterize acoustic signals. Based on this, the most common epipelagic schooling fish were sand lance Ammodytes hexapterus and immature herring Clupea harengus pallasi, and less commonly anchovy Engraulis mordax, smelt Allosmerus elongatus and Hypomesus pretiosus, and the juveniles of salmonids Oncorhynchus spp., rockfish Sebastes spp., sable fish Anoplopoma fimbria), and other species (Hay et al. 1992, Burger et al. 1993, Davoren \& Burger 1999). Euphausiids Thysanoessa spinifera and Euphausia pacifica are abundant in deeper water (>50 m) during daylight off Vancouver Island but are often adducted into surface waters or remain at the surface during daylight to spawn (Fulton \& LeBrasseur 1984, Mackas 1992, Mackas et al. 1997, Allen et al. 2001). On several surveys in late summer and autumn, we encountered large surface schools of euphausiids, usually accompanied by mixed-species flocks of seabirds. Traces made by larger fish, such as salmonids and spiny dogfish Squalus acanthias, could be identified by the solitary, bold traces and were disregarded because they were not taken by birds. Pacific hake, common in this area but too large to be taken by seabirds, were usually $>50 \mathrm{~m}$ deep (Mackas et al. 1997) and not likely to be included in our hydroacoustic sampling. Our interpretation of sounder traces excluded near-surface interference caused by waves and diffuse back-scatter from small plankton (e.g. copepods) but included denser schools of larger zooplankton, which were primarily euphausiids. Based on these observations, published data and consultations with a hydroacoustic expert (D. Mackas, pers. comm.), we are confident that the majority of acoustic signals observed in this study were schooling fish or euphausiids, both primary prey of seabirds in our study area.

Spatial grouping and relationships with prey were examined for all bird species for which there were sufficient data. Data were also pooled within families for common birds (gulls Laridae, alcids Alcidae) and in 3 foraging guilds (divers, surface-feeders and shearwaters). Diving birds were predominantly alcids but included loons, cormorants and grebes. Surfacefeeders were predominantly gulls but included fulmars, storm-petrels, phalaropes and an occasional jaeger. Shearwaters, which usually forage at the surface but are also accomplished divers (Burger 2001), were treated as a separate foraging guild.

Comparison between birds and prey focused on birds seen sitting on the water, which were more likely to be foraging than flying birds. For many species which feed at the surface, including most procellariiforms, phalaropes and gulls, the time on the wing might, however, included active foraging. For these species, we also considered the combined counts of birds on the water and flying, in addition to the birds on the water.

Following Morgan et al. (1991), we defined the seasons as winter (16 December to 15 March), spring (16 March to 15 June), summer (16 June to 15 September) and autumn (16 September to 15 December).

Neighbour K analysis. The spatial scales of aggregations within seabird species, among different species 
of seabirds, and between seabirds and prey, were calculated using neighbour K analysis (O'Driscoll 1998, O'Driscoll et al. 2000). Each analysis calculated patch radius, which measures the spatial scale at which aggregations occur, and crowding, which measures the intensity of aggregation (O'Driscoll 1998). Patch radius is also known as patch length (O'Driscoll 1998), scale of aggregation (Davoren 2000, Davoren et al. 2002, 2003) and ambit radius (O'Driscoll et al. 2000). We prefer the term patch radius because it emphasises the typical horizontal dimension of a patch in both directions of the transect line, i.e. along radii.

Essentially, the neighbour $\mathrm{K}$ analysis calculates, for each bird within the transect (or each unit of prey abundance), the mean number of other birds (or other prey scores) within an increasing patch radius (starting with spatial units of $250 \mathrm{~m}$ ) of the bird's location. The mean distribution is then calculated for each bird (or prey score) within the transect. Crowding is the mean number of 'extra' neighbours (i.e. more than expected) from a random distribution of the birds along the transect, plotted against the distance along the transect (O'Driscoll 1998). The mean number of 'extra' neighbours for each spatial unit along the transect is generated by comparing the actual number of neighbouring birds, in increasing numbers of adjacent spatial units, with a randomly-generated distribution. Following O'Driscoll (1998), we set the criterion for significant difference from randomly distributed data to be 0.01 . Patch radius was determined as the distance at which there was the first peak in mean number of 'extra' neighbours and crowding was taken to be the value of the mean number of 'extra' neighbours at that point.

Univariate neighbour $\mathrm{K}$ analyses calculated the patch radius and crowding for each bird species (with more than 5 individuals in a transect), group of species or prey, without considering interactions with other species or groups. Bivariate neighbour K analyses considered whether the distribution of one species or group (seabirds) was significantly clumped or over-dispersed relative to the distribution of a second species or group (prey). Bivariate bird-prey analyses were restricted to transects with more than 10 of each group being compared.

Statistical methods. We examined whether species and foraging guilds had distinctive patch radii and mean crowding, by comparing species within taxonomic families and by comparisons among the 3 guilds (surface-feeders, divers and shearwaters). Comparisons were made using the General Linear Model (GLM) in SPSS 10, with $\alpha$ set at 0.05 . The residuals were examined for non-normality; the few deviations from normality in the large number of tests we did were considered trivial and ignored. If a comparison included a species or guild in which bird density sig- nificantly affected patch radius or crowding, we tested these variables twice: with and without density as a covariate. Including density as a covariate controlled for the strong seasonal effects of bird density, especially on crowding. It was also deemed necessary to compare species and guilds without including density as a covariate, because variable density was an integral component of each species foraging niche and so, could not be ignored.

\section{RESULTS}

\section{Densities of seabirds}

Seabird densities on the shelf showed a strong seasonal trend, peaking in late summer through autumn (July to November; Fig. 2). Dominant groups were Procellariiformes (especially sooty shearwater Puffinus griseus, northern fulmar Fulmarus glacialis and forktailed storm-petrel Oceanodroma furcata), phalaropes (red-necked Phalaropus lobatus and red phalarope P. fulicaria), gulls (especially California gull Larus californicus, glaucous-winged gull L. glaucescens and, at times, herring gull $L$. argentatus, Sabine's gull Xema sabini and black-legged kittiwake Rissa tridactyla) and alcids (especially common murre Uria aalge and, to a lesser extent, Cassin's auklet Ptychoramphus aleuticus, rhinoceros auklet Cerorhinca monocerata and marbled murrelet Brachyramphus marmoratus). All of the common species, except the resident glaucouswinged gull, showed strong seasonal variations in density (Fig. 2; Burger 2003).

\section{Variations in patch radius and mean crowding in seabirds}

For most species, whether flying or on the water, there was no significant correlation between patch radius and bird density (Pearson correlation, $\mathrm{p}>0.05$ ). The exceptions were significant positive correlations in phalaropes (pooled counts for birds flying and on the water, $\mathrm{r}=0.994, \mathrm{p}<0.001, \mathrm{n}=9$ ), glaucous-winged gulls flying $(\mathrm{r}=0.521, \mathrm{p}=0.011, \mathrm{n}=23)$, common murres on the water $(r=0.406, p=0.049, \mathrm{n}=24)$, rhinoceros auklets on the water $(r=0.620, p=0.024, n=13)$ and in pooled data from all diving birds on the water or flying $(\mathrm{r}=0.460, \mathrm{p}=0.018, \mathrm{n}=26)$. Conversely, we found significant positive correlations between crowding and density for all bird species whether flying or on the water (Pearson correlation, $\mathrm{p}<0.01$ ), except for rhinoceros auklets on the water $(r=0.396, p=0.180$, $\mathrm{n}=13$ ). For all bird groups showing significant effects of density, we therefore considered density as a covari- 
ate when testing seasonal variations of patch size or crowding.

Among the common species (Table 1), significant seasonal variations in patch radius were found only in common murres on the water, which showed a slight increase in patch radius during summer (Fig. 3; GLM with density as covariate, $F_{3,19}=3.20, p=0.047$ ). With data pooled into foraging guilds (Fig. 4), significant seasonal variation in patch radius was found in surface-feeding birds on the water and flying (GLM with density as covariate, $F_{3,21}=3.72, p=0.027$ ) but not shearwaters or diving birds, whether on the water or flying ( $p>0.05$ in each case).

We found strong seasonal patterns in crowding (Fig. 4) but these trends were not statistically significant in any species or guild when density was included
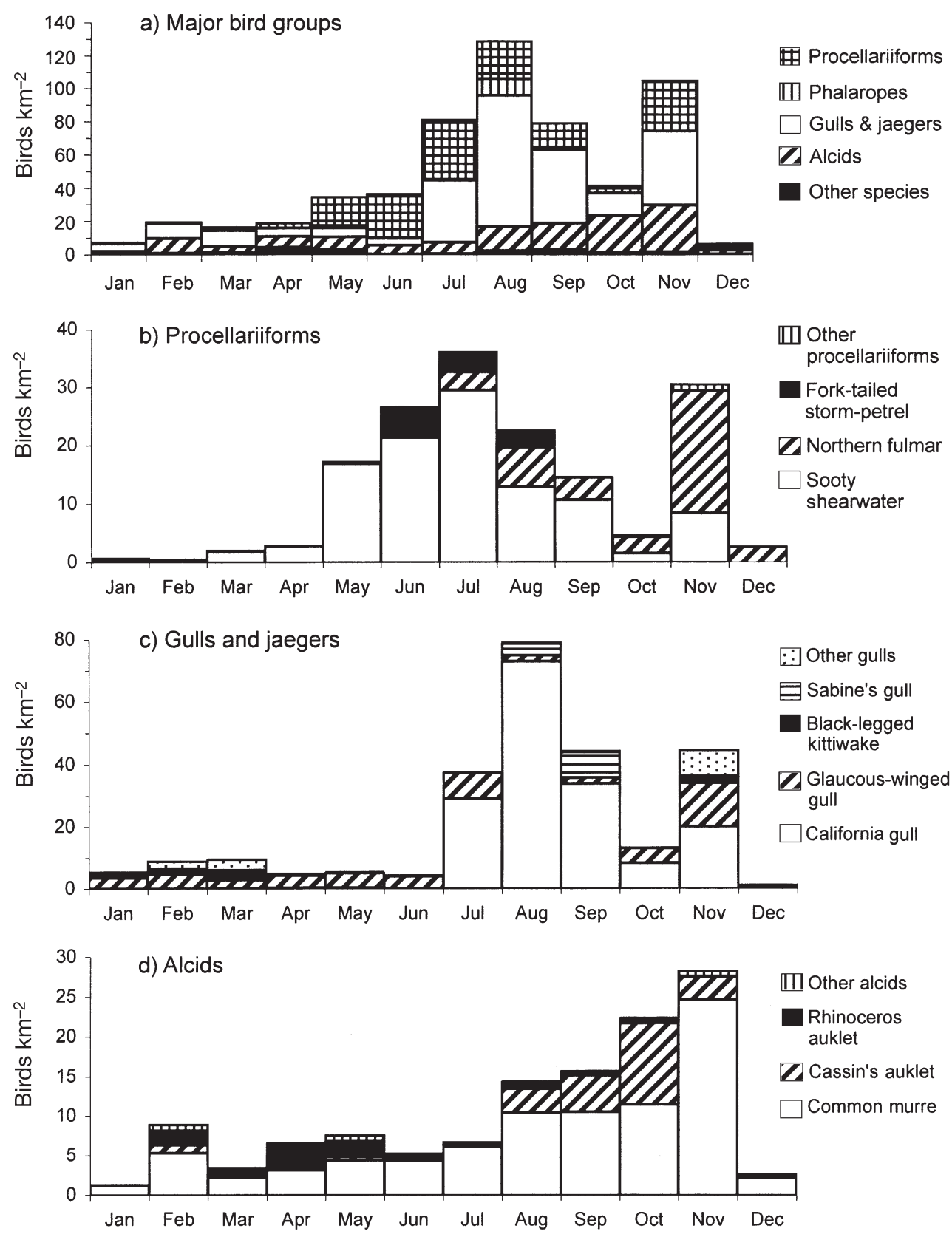

Fig. 2. Mean monthly densities of (a) the major families of birds, (b) species of procellariiforms (Procellariiformes), (c) species of gulls and jaegers (Laridae), and (d) species of alcids (Alcidae) recorded in vessel surveys off southwest Vancouver Island, 1993 to 1995. Note that the y-axis scales vary 
as a covariate (GLM, p > 0.05 in each case). The seasonal trends in crowding were, therefore, driven by seasonal changes in bird density rather than by seasonal variations in flocking behaviour.

For most common species, and the shearwater and surface-feeding guilds, the mean patch radius was consistently larger for flying birds than for birds on the water (Table $1 \&$ Fig. 4). The only exceptions to this trend were rhinoceros auklets, which consistently showed the opposite pattern in all seasons (Fig. 3), and common murres (Fig. 3) and diving birds collectively (Fig. 4), which showed no consistent patterns across the seasons.

For most species and all 3 guilds, the mean crowding was consistently smaller for flying birds than for birds on the water (Table $1 \&$ Figs. $3 \& 4$ ). The exceptions here were Cassin's auklets (Fig. 3) and several species

Table 1. Mean $( \pm \mathrm{SD})$ patch radius and crowding within each taxonomic group and foraging guild, using pooled year-round data. See text for statistical tests

\begin{tabular}{|c|c|c|c|}
\hline Bird group & $\begin{array}{c}\text { Patch radius } \\
(\mathrm{km})\end{array}$ & $\begin{array}{l}\text { Crowding } \\
\text { (birds) }\end{array}$ & $\begin{array}{c}\text { No. of } \\
\text { surveys }\end{array}$ \\
\hline \multicolumn{4}{|l|}{ Procellariiformes on water } \\
\hline Sooty shearwater & $3.5 \pm 3.0$ & $143 \pm 185$ & 17 \\
\hline Northern fulmar & $1.6 \pm 2.1$ & $97 \pm 155$ & 9 \\
\hline Fork-tailed storm-petrel & $1.7 \pm 1.8$ & $51 \pm 34$ & 3 \\
\hline \multicolumn{4}{|l|}{ Procellariiformes flying } \\
\hline Sooty shearwater & $7.2 \pm 8.5$ & $56 \pm 115$ & 22 \\
\hline Northern fulmar & $11.9 \pm 9.4$ & $26 \pm 31$ & 14 \\
\hline Fork-tailed storm-petrel & $7.3 \pm 6.0$ & $70 \pm 107$ & 7 \\
\hline Phalaropes on the water & $1.5 \pm 2.4$ & $38 \pm 58$ & 7 \\
\hline Phalaropes flying & $1.6 \pm 3.3$ & $13 \pm 15$ & 8 \\
\hline \multicolumn{4}{|l|}{ Gulls on the water } \\
\hline California gull & $3.0 \pm 3.4$ & $867 \pm 1576$ & 14 \\
\hline Glaucous-winged gull & $3.4 \pm 4.1$ & $55 \pm 105$ & 19 \\
\hline \multicolumn{4}{|l|}{ Gulls flying } \\
\hline California gull & $5.6 \pm 7.1$ & $233 \pm 546$ & 12 \\
\hline Glaucous-winged gull & $4.0 \pm 4.6$ & $7 \pm 9$ & 23 \\
\hline \multicolumn{4}{|l|}{ Alcids on the water } \\
\hline Cassin's auklets & $3.8 \pm 3.2$ & $33 \pm 65$ & 16 \\
\hline Common murre & $4.9 \pm 4.0$ & $39 \pm 43$ & 24 \\
\hline Rhinoceros auklet & $1.2 \pm 1.0$ & $8 \pm 11$ & 13 \\
\hline Marbled murrelet & $1.0 \pm 0.9$ & $3 \pm 2$ & 6 \\
\hline \multicolumn{4}{|l|}{ Alcids flying } \\
\hline Cassin's auklets & $8.8 \pm 9.3$ & $55 \pm 90$ & 9 \\
\hline Common murre & $4.8 \pm 7.2$ & $11 \pm 24$ & 21 \\
\hline Rhinoceros auklet & $0.5 \pm 0.4$ & $3 \pm 4$ & 12 \\
\hline \multicolumn{4}{|c|}{ Foraging guilds - birds on water } \\
\hline Shearwaters & $3.5 \pm 3.1$ & $143 \pm 185$ & 17 \\
\hline Surface-feeding birds & $4.3 \pm 5.1$ & $574 \pm 1301$ & 23 \\
\hline Diving birds & $5.0 \pm 4.5$ & $50 \pm 86$ & 25 \\
\hline \multicolumn{4}{|l|}{ Foraging guilds - birds flying } \\
\hline Shearwaters & $7.3 \pm 8.5$ & $58 \pm 117$ & 22 \\
\hline Surface-feeding birds & $7.6 \pm 9.4$ & $127 \pm 358$ & 26 \\
\hline Diving birds & $5.9 \pm 6.5$ & $28 \pm 57$ & 25 \\
\hline
\end{tabular}

which forage on the wing or frequently fly while foraging (forked-tailed storm-petrels, phalaropes, Sabine's gull and black-legged kittiwake). The general yearround pattern for most species was, therefore, that flying birds occurred in smaller aggregations, spread over a wide area, whereas birds on the water tended to occur in smaller areas, but in larger flocks.

\section{Variations in patch radius and crowding among species and guilds}

Comparisons of patch radius and crowding among the species within taxonomic groups or guilds were difficult, because the large seasonal variability in density, crowding and, to a lesser extent, patch radius, resulted in weak tests. Within the Procellariiformes, we found no significant differences in patch radii and crowding among the 3 common species, for birds on the water or flying (Table 1; GLM, p > 0.1 in all cases; crowding tested with and without density as a covariate).

Within the gulls, there were no differences between California and glaucous-winged gulls in the patch radii for either birds on the water or flying (Table 1; GLM, p > 0.4 in both cases). California gulls tended to have higher crowding than glaucous-winged gulls, but not when density was controlled as a covariate (Table 1 ; GLM, $p>0.2$ for birds on the water or flying). Other gull species had insufficient data for comparisons.

Among the alcids, Cassin's auklets and common murres had larger patch radii than rhinoceros auklets and marbled murrelets (Table $1 ; F_{3,55}=5.30, \mathrm{p}=0.003$ for birds on the water; $F_{2,37}=4.05, \mathrm{p}=0.026$ for birds flying). We found no difference among alcid species in crowding for birds on the water (Table $1 ; \mathrm{p}>0.6$ with or without density as a covariate), but for flying birds, common murres and Cassin's auklets were in larger groups than rhinoceros auklets $\left(F_{2,36}=11.59\right.$, $\mathrm{p}<0.001$ with density as a covariate).

The mean patch radii were similar for the 3 foraging guilds: 3.9 to $5.0 \mathrm{~km}$ for birds on the water and 5.9 to $7.9 \mathrm{~km}$ for flying birds (Table 1; GLM: $\mathrm{p}>0.6$ in each case, with or without density as a co-variate). Similarly, despite the marked differences in mean crowding among the 3 guilds, these were not statistically significant due to the high variance in all guilds (Table 1; GLM: $p>0.07$ in each case, with or without density as a covariate). 

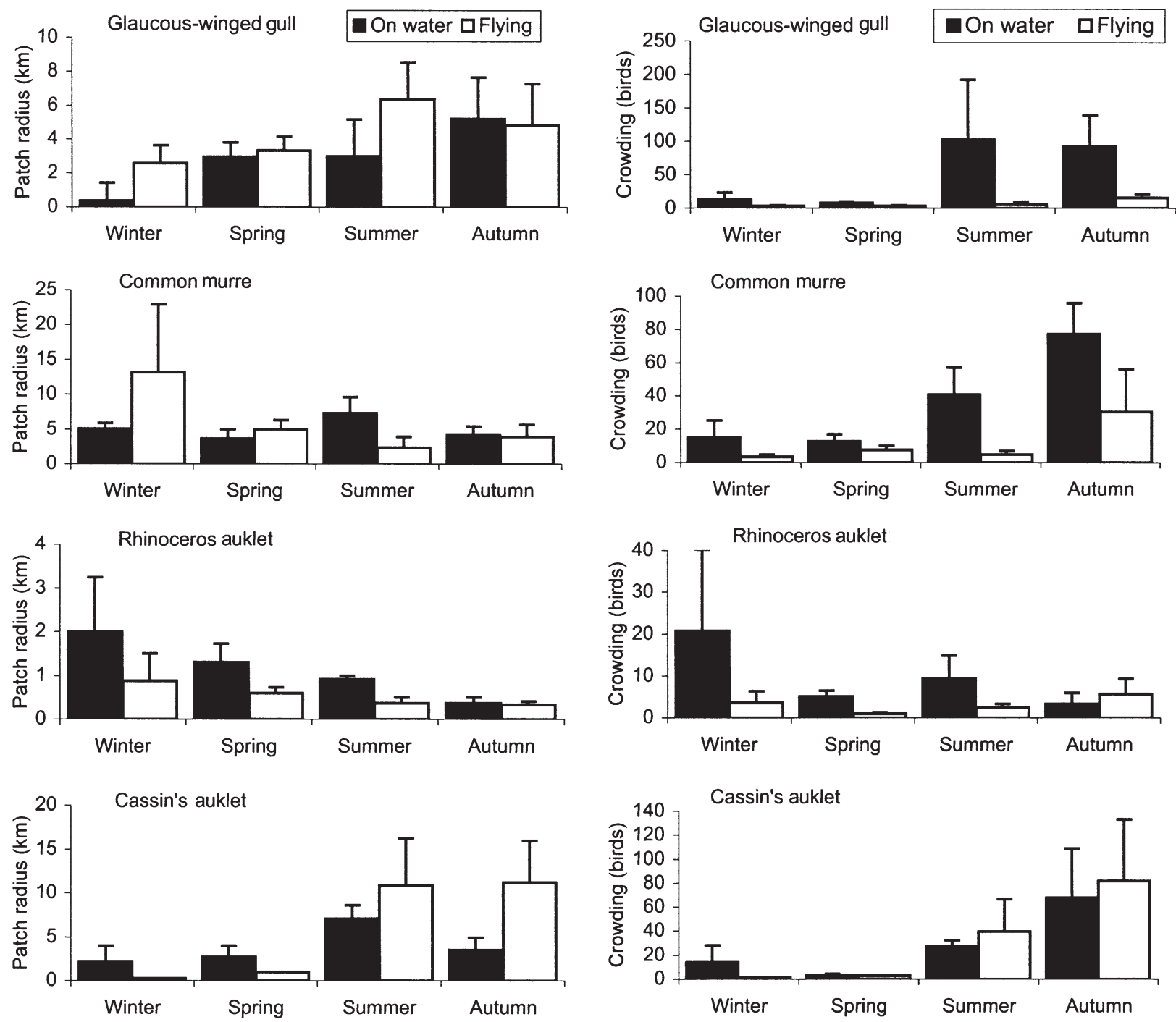

Fig. 3. Mean (+SE) patch radius (left graphs) and crowding (right graphs) in each season of 4 common species found year-round off southwest Vancouver Island. Birds recorded as being on the water and flying are shown separately

\section{Spatial and seasonal distribution of prey}

Relative prey abundance showed a consistent decline with increasing depth within the 1 to $40 \mathrm{~m}$ sampling range (Fig. 5a). This trend held for all seasons but was less marked in winter, when prey was scarce at all depths. Prey abundance increased from winter through spring and summer, then declined slightly in autumn, remaining higher than in spring. In all transects, there were many spatial units $(1 \mathrm{~min}$ travel intervals) without evidence of prey; on average, prey schools were present within the 1 to $40 \mathrm{~m}$ range in $7 \%$ of the intervals in winter, $26 \%$ in spring, $51 \%$ in summer and $28 \%$ in autumn. Prey abundance scores were highly variable among the transects in each sea- son (as indicated by the high SD in seasonal means; Fig. 5a) and also within each transect (as indicated by the high coefficient of variation within transects; Fig. 5b).

Patch radius for the near-surface $(1$ to $10 \mathrm{~m})$ prey had a year-round mean of $4.1 \pm 3.0$ (SD) $\mathrm{km}$ (range 0.5 to $12.0 \mathrm{~km}$ ) and showed no correlation with mean prey scores per survey $(r=0.31, p=0.224, n=17$ surveys $)$. Seasonal means of prey patch radius showed high variance (Fig. 6) but no significant differences among the seasons (GLM, $\left.F_{3,13}=1.02, \mathrm{p}=0.415\right)$. Patch radius for the complete 1 to $40 \mathrm{~m}$ depth range averaged $6.1 \pm 5.7$ (SD) $\mathrm{km}$ (range 0.5 to $21.0 \mathrm{~km}$ ) and was significantly correlated with mean prey score per survey $(\mathrm{r}=0.48, \mathrm{p}$ $=0.05, \mathrm{n}=17$ ). With mean prey score controlled as a 

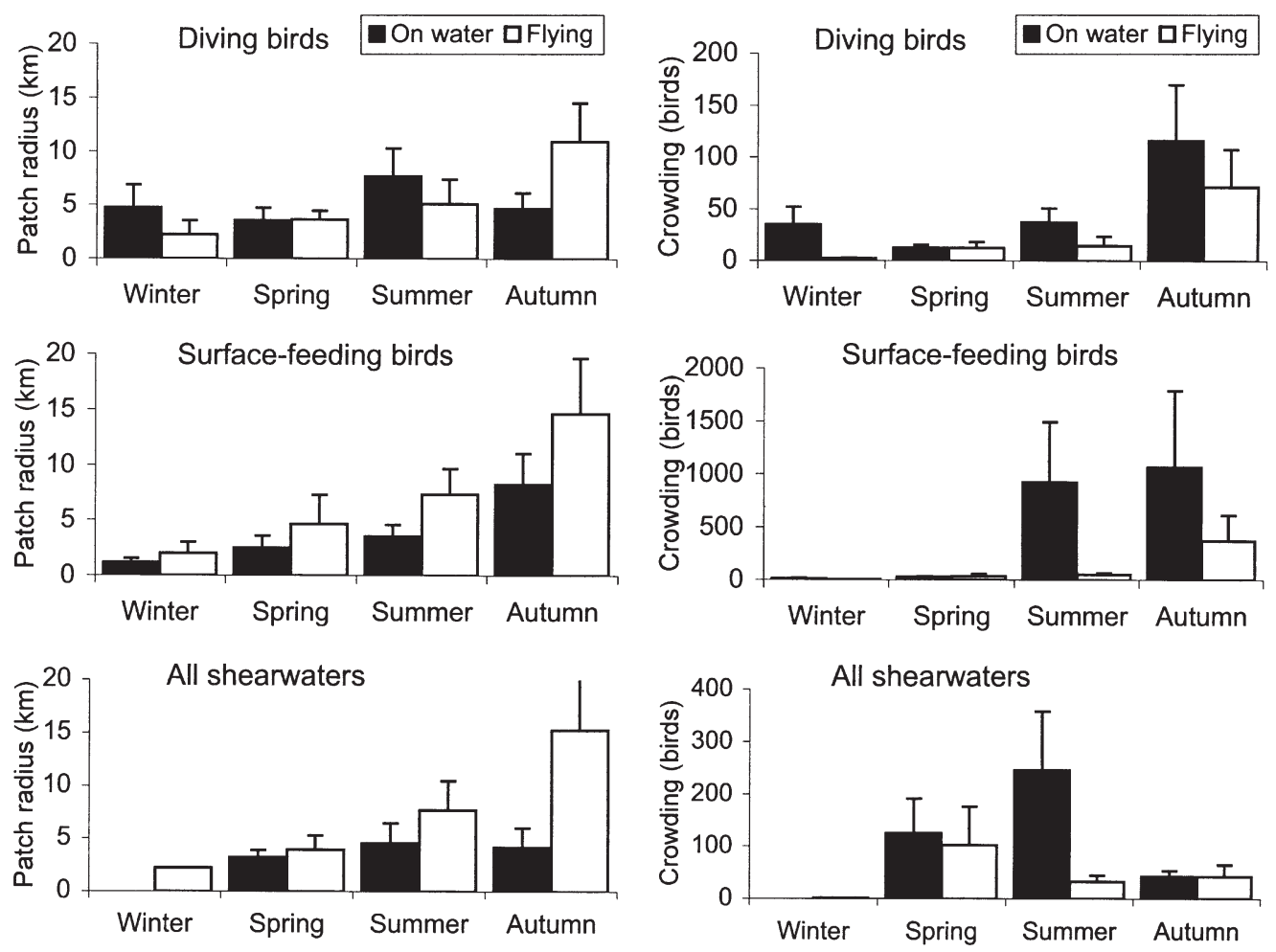

Fig. 4. Mean (+SE) patch radius (left graphs) and crowding (right graphs) of the 3 foraging guilds off southwest Vancouver Island in each season. Birds recorded as being on the water and flying are shown separately. The y-axis scale varies in the graphs on the right

b)

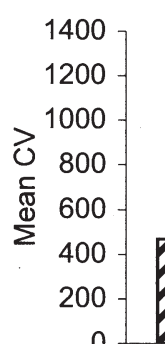

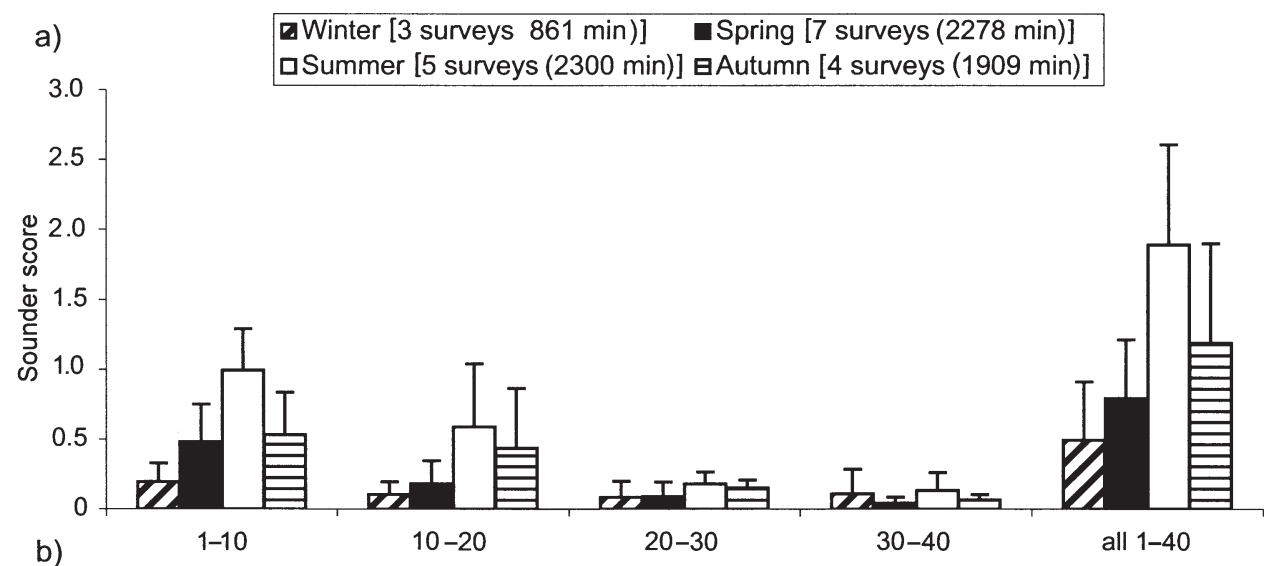

WWinter [3 surveys $861 \mathrm{~min})$ ] ESpring [7 surveys (2278 $\mathrm{min})$ ]
Fig. 5. Variations in relative prey abundance with depth and seasons off southwest Vancouver Island. The upper graph (a) shows the seasonal mean $(+\mathrm{SD})$ of the average prey score $\mathrm{min}^{-1}$ within each transect. The SD bars indicate the variability among surveys within each season. The lower graph (b) shows the mean coefficient of variation (CV) of prey scores as a measure of the average variability within each survey 

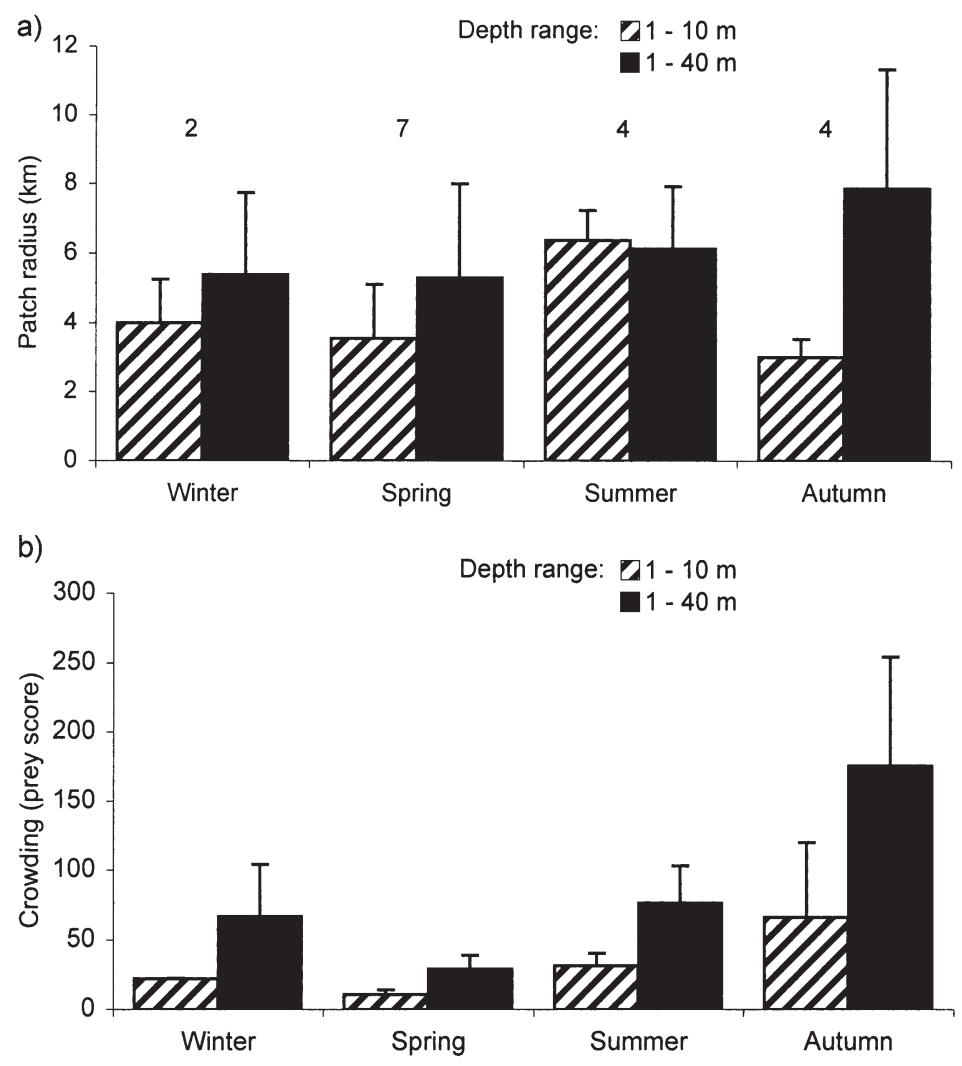

Fig. 6. Seasonal changes in (a) the mean $(+\mathrm{SE})$ patch radius $(\mathrm{km})$ and (b) mean (+SE) crowding (prey score) of potential prey schools off southwest Vancouver Island. The sample sizes shown are the number of surveys with sufficient data for neighbour $\mathrm{K}$ analysis of prey scores the less common bird species). Significant associations between birds and near-surface (1 to $10 \mathrm{~m}$ ) and total prey ( 1 to $40 \mathrm{~m}$ ) samples were found for most of the bird species and foraging guilds tested (Table 2). Significant associations were more likely for common than rarer species, but no other variations among species, families or foraging guilds were obvious.

For surveys in which there were significant associations between birds and prey, we calculated the patch radius and mean crowding using 1 to 10 and 1 to $40 \mathrm{~m}$ prey samples (Table 3). Mean crowding in these bird-prey associations was significantly positively correlated with bird density for California gulls (Pearson $\mathrm{r}=0.911, \mathrm{p}=0.012, \mathrm{n}=6$ ), all gulls pooled ( $\mathrm{r}=0.900, \mathrm{p}<0.001, \mathrm{n}=9$ ), all alcids pooled $(r=0.687, p=0.028, n=10)$, all surfacefeeding birds pooled $(\mathrm{r}=0.859, \mathrm{p}=0.003, \mathrm{n}=9$ ) and all diving birds pooled $(r=0.687, p=0.020$, $\mathrm{n}=11$ ). Patch radius was never significantly correlated with bird density for any species or group and neither patch radius nor crowding were ever correlated with prey abundance scores ( $p>0.05$ in each case). We found no significant seasonal variations in the patch radii of bird-prey associations, nor in mean crowding for common species and guilds (GLM, with bird density as a covariate for species or groups where it was significantly correlated with covariate, the 1 to $40 \mathrm{~m}$ prey patch radius showed no significant seasonal variation (Fig. 6 ; GLM; $F_{3,12}=0.71$, $\mathrm{p}=0.56)$.

In the 1 to $10 \mathrm{~m}$ depth zone, prey crowding showed no significant correlation with abundance score $(\mathrm{r}=$ $0.15, \mathrm{p}=0.578, \mathrm{n}=17$ surveys) and no significant variation among the seasons (Fig. 6; $F_{3,13}=0.948, \mathrm{p}=$ 0.446). In the overall prey sample (1 to $40 \mathrm{~m}$ depth), crowding scores were significantly correlated with mean prey scores per survey $(r=0.54, p=0.027, n=17)$ and showed a significant seasonal effect (GLM with mean prey score as a covariate, $F_{3,12}=3.99, \mathrm{p}=0.035$ ). With crowding corrected for mean abundance score, the marginal means of prey crowding were higher in autumn (169) and winter (103) than spring (58) or summer (13).

\section{Spatial associations between birds and prey}

Out of 19 surveys in which prey abundance was recorded, prey and bird densities were sufficient for bivariate neighbour $\mathrm{K}$ analysis in 15 surveys (fewer for
Table 2. Percentage of surveys in which there were significant spatial associations between birds on the water and relative prey abundance in the near-surface waters $(1$ to $10 \mathrm{~m})$ and in the total water column sampled (1 to $40 \mathrm{~m}$ ). Sample size is the number of surveys with sufficient data to compare birds and prey

\begin{tabular}{|lccc|}
\hline Species or guild & $\begin{array}{c}\text { Near-surface } \\
\text { prey } \\
(1-10 \mathrm{~m})\end{array}$ & $\begin{array}{c}\text { Total prey } \\
\text { sample } \\
(1-40 \mathrm{~m})\end{array}$ & $\begin{array}{c}\text { No. of } \\
\text { surveys }\end{array}$ \\
\hline All shearwaters & 55 & 64 & 11 \\
Northern fulmar & 20 & 20 & 5 \\
Forked-tailed storm-petrel & 20 & 20 & 5 \\
Phalaropes & 57 & 43 & 7 \\
California gull & 75 & 75 & 8 \\
Glaucous-winged gull & 25 & 67 & 12 \\
All gulls pooled & 40 & 60 & 15 \\
Cassin's auklets & 70 & 70 & 10 \\
Common murre & 67 & 53 & 15 \\
Rhinoceros auklet & 22 & 22 & 9 \\
All alcids pooled & 67 & 67 & 15 \\
All surface-feeding birds & 53 & 60 & 15 \\
All diving birds & 73 & 67 & 15 \\
All birds & 80 & 73 & 15 \\
aResults were identical when sooty shearwaters were \\
analysed separately & \multicolumn{3}{|l}{} \\
\end{tabular}


crowding; $\mathrm{p}>0.05$ in each case), but small samples gave these tests low power (generally power $<0.2$ ).

The overall mean patch radii show no consistent differences among the bird species or foraging guilds (Table 3). Mean crowding was less consistent among the species and guilds, as expected by the differences in density. Both patch radii and crowding in diving birds and shearwaters tended to be slightly higher when compared with the 1 to $40 \mathrm{~m}$ prey sample than with the 1 to $10 \mathrm{~m}$ sample. We did not compare surface-feeding birds with the 1 to $40 \mathrm{~m}$ prey sample. Surface feeding species and shearwaters, generally had higher crowding at prey patches than diving birds.

In pooled data for birds of all species, whether on the water or flying, associations with prey in the 1 to $10 \mathrm{~m}$ depth range schools typically occurred within a patch radius of 4 to $5 \mathrm{~km}$ and involved about 40 birds, whereas associations with prey in the larger 1 to $40 \mathrm{~m}$ range were typically in patches with radii of 7 to $8 \mathrm{~km}$ and involved about 100 birds (Table 3). The high SDs indicate considerable variation around these mean values.

\section{DISCUSSION}

\section{Univariate measures of patch radius and crowding in birds}

Most birds recorded over the shelf off Vancouver Island were migrants which bred far from the study area and their densities varied significantly through the seasons (Morgan et al. 1991, Burger 2003). Seasonal variations in density affected our ability to measure aggregation; significant measures of crowding and patch radius were possible only when many birds were present. Crowding was usually significantly affected by bird density; this was not unexpected since crowding is a measure of numerical aggregation, but even at high densities, crowding might be low if the birds maintain small patch radii (as did rhinoceros auklets). After controlling for density, we found few differences in crowding among species or among seasons. Patch radius, however, was seldom significantly affected by bird density, giving some confidence that the differences among species and guilds, and among seasons were due to behavioural responses and not density per se. The ability to separate spatial aggregation from density effects is one of the strengths of the neighbour K method.

The general year-round pattern for most species was that flying birds occurred in smaller aggregations spread over larger patches than birds on the water. This trend was weak for diving birds but strong for surface-feeding birds and shearwaters. Although many species, especially surface-feeding birds, seek food while on the wing, it is a reasonable assumption, applied in most pelagic studies, that counts of birds on the water are more likely to reflect foraging situations than counts of flying birds (Tasker et al. 1984, Logerwell \& Hargreaves 1996). The differences in crowding and patch radius between flying birds and those on the water are consistent with the network-foraging concept, whereby seabirds seek food by flying independently, spread over large tracts of ocean, but rapidly aggregate on the water in larger flocks where accessible prey have been detected (Wittenberger \& Hunt 1985). In our study area (Porter \& Sealy 1981, Davoren \& Burger 1999) and elsewhere (Sealy 1973, Hoffman et al. 1981), mixed-species flocks of birds typically aggregate at near-surface prey patches and birds tend to arrive singly. Foraging efficiency can be higher in flocks than for solitary birds (Götmark et al. 1986), although inhibition, interference competition and resource depletion may be negative consequences of flock feeding in some circumstances (Hoffman et al. 1981, Piatt 1990, Davoren \& Burger 1999, Maniscalco et al. 2001).

There was no clear evidence of species-specific patch radius or crowding. Patch radius remained relatively constant throughout the year, typically 2 to $8 \mathrm{~km}$ for most species, despite large seasonal changes in density and mean crowding. Patch radius seldom differed significantly among species within families (Table 1) and was similar among the 3 foraging guilds (Fig. 4). The similarity in spatial aggregation patterns was probably because the various species, despite different foraging tactics, were responding to the same mechanisms causing prey aggregations, as discussed below.

\section{Spatial distribution and aggregation of prey}

Our study provides the first year-round measures of relative prey abundance applicable to seabirds feeding in the epipelagic zone in the temperate North Pacific. We found a striking decline in prey abundance with depth; the upper $10 \mathrm{~m}$ consistently provided the highest and least variable prey scores in all seasons. Local alcids typically feed in this zone, even though they are capable of much deeper dives (Burger 1991, Burger et al. 1993).

Prey abundance varied seasonally and was highest in summer, followed by autumn and spring. Compared to winter values, summer prey scores were 4 -fold higher (5-fold in the 1 to $10 \mathrm{~m}$ range) and prey were found in 7 times more sampling intervals (50 vs $7 \%$ ). High prey densities during summer and, to a lesser extent, autumn and spring are a consequence of 
Table 3. Mean $( \pm$ SD) patch radius and crowding for significant spatial associations between birds and prey abundance measured in near-surface waters (1 to $10 \mathrm{~m}$ depth) and in the complete prey sample (1 to $40 \mathrm{~m}$ depth). The sample size (n) was the number of surveys in which there were significant associations between birds and prey

\begin{tabular}{|c|c|c|c|c|c|}
\hline Species or guild & Category & Prey depth (m) & Patch radius $(\mathrm{km})$ & Crowding (birds) & $\mathrm{n}$ \\
\hline All shearwaters ${ }^{a}$ & On water & $1-10$ & $6.2 \pm 3.3$ & $76 \pm 64$ & 6 \\
\hline All shearwaters ${ }^{a}$ & On water & $1-40$ & $6.4 \pm 2.7$ & $151 \pm 104$ & 7 \\
\hline Northern fulmar & On water + flying & $1-10$ & $9.1 \pm 10.8$ & $77 \pm 94$ & 2 \\
\hline Forked-tailed storm-petrel & On water + flying & $1-10$ & 2.0 & 6 & 1 \\
\hline Phalaropes & On water + flying & $1-10$ & $2.7 \pm 1.5$ & $9 \pm 4$ & 4 \\
\hline California gull & On water + flying & $1-10$ & $3.9 \pm 3.3$ & $63 \pm 91$ & 6 \\
\hline Glaucous-winged gull & On water + flying & $1-10$ & $2.8 \pm 2.3$ & $46 \pm 88$ & 5 \\
\hline All gulls pooled & On water & $1-10$ & $3.7 \pm 2.8$ & $65 \pm 91$ & 6 \\
\hline All gulls pooled & On water + flying & $1-10$ & $3.8 \pm 2.9$ & $43 \pm 76$ & 9 \\
\hline Cassin's auklets & On water & $1-10$ & $3.8 \pm 3.0$ & $40 \pm 51$ & 7 \\
\hline Cassin's auklets & On water & $1-40$ & $5.3 \pm 3.5$ & $90 \pm 82$ & 7 \\
\hline Common murre & On water & $1-10$ & $3.2 \pm 2.5$ & $25 \pm 48$ & 10 \\
\hline Common murre & On water & $1-40$ & $4.3 \pm 3.2$ & $62 \pm 81$ & 8 \\
\hline Rhinoceros auklet & On water & $1-10$ & $2.3 \pm 0.7$ & $18 \pm 24$ & 2 \\
\hline Rhinoceros auklet & On water & $1-40$ & $1.9 \pm 1.2$ & $47 \pm 10$ & 2 \\
\hline All alcids pooled & On water & $1-40$ & $4.8 \pm 2.9$ & $50 \pm 67$ & 10 \\
\hline All surface-feeding birds & On water & $1-10$ & $4.1 \pm 3.1$ & $49 \pm 81$ & 8 \\
\hline All surface-feeding birds & On water + flying & $1-10$ & $3.9 \pm 2.9$ & $41 \pm 74$ & 9 \\
\hline All diving birds & On water & $1-10$ & $3.6 \pm 2.6$ & $23 \pm 44$ & 11 \\
\hline All diving birds & On water & $1-40$ & $4.9 \pm 2.8$ & $50 \pm 66$ & 10 \\
\hline All birds & On water & $1-10$ & $4.1 \pm 2.9$ & $40 \pm 63$ & 12 \\
\hline All birds & On water & $1-40$ & $7.0 \pm 3.9$ & $100 \pm 101$ & 11 \\
\hline All birds & On water + flying & $1-10$ & $5.3 \pm 2.8$ & $42 \pm 62$ & 10 \\
\hline All birds & On water + flying & $1-40$ & $8.4 \pm 7.7$ & $99 \pm 106$ & 10 \\
\hline
\end{tabular}

increased local productivity during these seasons, augmented by the seasonal onset of upwelling processes bringing euphausiids and other zooplankton into the shelf waters, and creating fronts at which they and other prey taken by seabirds can be concentrated (Denman et al. 1981, Mackas 1992, Mackas \& Galbraith 1992, Mackas et al. 1997; Burger 2003 for mesoscale effects on seabirds). Prey crowding, as expected, was strongly correlated with prey abundance scores, although prey abundance was highest in summer (Fig. 5), whereas prey crowding was highest in autumn (Fig. 6). One possible explanation is that smaller schools of fish and macro-zooplankton coalesced in late summer and autumn, prior to moving offshore or into deep water for the winter (Hay et al. 1992, Mackas \& Galbraith 1992). The combination of high densities and dense aggregations of near-surface prey in summer and autumn explains the large influx of non-breeding migrant seabirds, consistently reported over the shelf off Vancouver Island at this time (Morgan et al. 1991, Hay 1992, Burger 2003).

Prey were typically aggregated in horizontal patches of 4 to $6 \mathrm{~km}$ radius and although there was high variability among surveys, seasonal trends in patch radii were not significant. This, together with the relatively constant patch radii of seabirds throughout the year, which rarely differed among species, suggests that different seabird species were responding to the same mechanisms resulting in prey aggregations, rather than exhibiting species-specific flocking and foraging behaviour. Patches of prey extending several $\mathrm{km}$ would be influenced more strongly by meso-scale oceanic effects, such as upwelling and the Juan de Fuca eddy (Burger 2003), than by small-scale tidal fronts and similar processes operating at scales of 100's of m (Hunt \& Schneider 1987).

\section{Spatial aggregation of seabirds and associations with prey}

Significant associations between birds and prey were found in most of our surveys with sufficient data for bivariate neighbour K analyses. The absence of significant associations within a survey might indicate a true lack of association between birds and prey (Vlietstra in press), but could also be due to confounding factors: the ability of the neighbour $\mathrm{K}$ method to detect significant associations might be highly sensitive to bird density and/or prey abundance score; birds might have been attracted to prey not detected by the sounder (within the upper $1 \mathrm{~m}$ or outside the sounder's 
sampling cone below the vessel); and the vessel might have caused prey schools to disperse. Most of these limitations are difficult to avoid and are found in other studies comparing birds with hydroacoustic prey estimates.

Bird species and guilds were typically associated with prey at patch radii of 2 to $8 \mathrm{~km}$ and univariate measures of bird patch radius (Table 1 ) were generally similar to the bivariate bird-prey patches (Table 3). This suggests that seabird spatial aggregation was strongly linked to prey patchiness and that different bird species were responding to similar cues. Other studies which sampled at fine-scale resolutions $(<1 \mathrm{~km})$ typically reported seabird aggregations or significant associations between birds and prey at scales of 1 to 5 or 1 to $10 \mathrm{~km}$ (reviews by Hunt 1997, Hunt et al. 1999, Schneider 2002).

Murres (Uria spp.) provide the most data in this regard, and the strongest associations between murres and prey were found at scales of 2 to $6 \mathrm{~km}$ in Newfoundland (common murres; Schneider \& Piatt 1986, Piatt 1990), 2 to $3 \mathrm{~km}$ in the northeast Atlantic (thickbilled murres Uria lomvia; Mehlum et al. 1999) and 3 to $4 \mathrm{~km}$ in this study (Table 3). Aggregations by murres at 2 to $4 \mathrm{~km}$ are likely nested within larger aggregations linked with larger oceanic processes. Fauchald et al. (2000) reported a hierarchical set of interactions between murres (both species pooled) and prey with significant associations at scales of $>300 \mathrm{~km}$, approximately $50 \mathrm{~km}$ and approximately $3 \mathrm{~km}$, but not at finer scales (minimum frame size $1 \mathrm{~km}$ ).

Although there appears to be some consistency in predator-prey patch aggregations among seabirds and our study indicates some inter-seasonal consistency too, patch sizes can be affected by prey availability and the other factors. Some studies report larger radii for bird-prey aggregations under spatial or temporal conditions with higher productivity. Davoren (2000) found that the bird-prey patch radii of rhinoceros auklets near our study area were significantly higher (2 to $14 \mathrm{~km}$ ) in 1 year when prey were more dispersed relative to other years $(0.5$ to $7 \mathrm{~km})$ when prey were more concentrated. Similarly, Davoren et al. (2003) found that patch radii of common murres and their prey off Newfoundland were larger in a productive area where prey was persistent in space and time (mean 2.6 $\pm \mathrm{SE}$ $0.4 \mathrm{~km}$ ) compared to a less productive area where prey was not persistent $(1.2 \pm$ SE $0.2 \mathrm{~km})$. With high prey densities, birds might have less need to track prey schools and at small scales, this could result in low spatial concordance between bird and prey patches (Vlietstra in press).

The strength of association with prey and patch size is also likely to be affected by the seabirds' energy demands, constraints imposed by breeding and stage within their annual cycle. For example, Davoren et al. (2002) found that when common murres were flightless during post-breeding moult, they had larger bivariate bird-prey patches compared to during prebreeding when they could fly. Breeding birds constrained to foraging near colonies might exhibit different associations with prey than non-breeding birds, although this was not evident in the seasonal trends of the 4 common species which bred in or near our study area (Fig. 3). We also did not find marked differences between these species and the non-breeding migrants, which made up the bulk of our samples.

\section{The need to test for spatial scale in predator-prey studies}

Failure to sample seabirds and their prey with fine spatial resolution $(<1 \mathrm{~km})$ and to test for the appropriate scale of spatial aggregation can lead to problems of interpretation. Comparisons between our data and 2 studies made near our study site illustrate this. First, Logerwell \& Hargreaves (1996) investigated bird-prey distributions off Vancouver Island using line transects and trawl net sampling of prey fish in the upper 10 to $15 \mathrm{~m}$. Using spectral analysis, they found significant positive associations between birds (common murres, and sooty and short-tailed shearwaters) and prey abundance at scales of 100's $\mathrm{km}$. At a smaller scale (minimum resolution of $6 \mathrm{~km}$ ), however, they found a negative association between bird densities and prey abundance, which they attributed to the disruptive effects of birds driving prey below the sampling range of their near-surface nets. We find this explanation unconvincing, because numerous studies, including ours and those reviewed above, show the abilities of murres and shearwaters to repeatedly locate and exploit fish patches near the surface. Several other explanations seem more likely. The spatial resolution used by Logerwell \& Hargreaves (1996) was probably too coarse to detect the associations which we found at 2 to $8 \mathrm{~km}$ radii. Both murres (Burger 1991) and shearwaters (Burger 2001) routinely forage deeper than the depths (upper 10 to $15 \mathrm{~m}$ ) sampled by Logerwell \& Hargreaves (1996) and they might, therefore, have missed schools being exploited by the birds. In addition, as these authors mention, some of the important prey species such as sand lance might have avoided the net. Finally, their study did not consider euphausiids and other macro-zooplankton which are important prey for shearwaters and murres (Vermeer et al. 1987, Hunt et al. 1996).

Second, Parrish et al. (1998) investigated associations between birds and prey off Cape Flattery, Washington (overlapping with our study area), at spatial 
bins of $1 \mathrm{~km}$. They found significant positive associations with prey at this scale for common murres but not for sooty shearwaters. The larger patch radii found for shearwaters in our study (on the water: typically 3 to $4 \mathrm{~km}$; flying: 3 to $15 \mathrm{~km}$ ) might explain this result.

\section{Implications for monitoring of birds at sea and assessing oil spills}

The resolution of maps and GIS databases used to monitor birds at sea is usually determined by some arbitrary scale (e.g. 1/4 degree blocks: Morgan et al. 1991; 5' $\times 5^{\prime}$ blocks: Ford et al. 1991) or by the resolution of the charts or GIS programs. Biologically determined spatial parameters are seldom considered. Our data suggest that appropriate scales for mapping aggregations of seabirds over the continental shelf at the finest resolution should be in the 1 to $10 \mathrm{~km}$ range. Smaller resolutions might erroneously show more random distributions of birds and larger ones would not capture the aggregations at prey concentrations. Spatial resolutions of 1 to $10 \mathrm{~km}$ are also appropriate for aerial surveillance in response to oil spills (Ford et al. 1991), in or for the use of satellite imagery to predict where bird aggregations might occur (Briggs et al. 1987, Haney 1989). Information on appropriate spatial scales is also essential for monitoring changes in distribution and behaviour of birds at sea in response to periodic (e.g. El Niño or Pacific Decadal Oscillation) or long-term (global climate change) ocean processes. Year-round studies of birds and prey in other areas are needed to confirm the relative uniformity of patch size among species and guilds, and across seasons, reported off Vancouver Island.

Acknowledgements. The study was funded by grants to A.E.B. from the Nestucca Trust Fund and NSERC Canada. Bamfield Marine Sciences Centre provided a vessel and accommodation. We thank the many volunteers and assistants, especially those who made repeated offshore cruises, including S. Beauchesne, M. Bentley, C. Engelstoft, C. Grant, A. Lawrence, K. Little, N. Mathews, K. Nordin, D. Renfrew, A. Stewart, C. Strauss and students from Bamfield Marine Station. For their important contributions, we thank: skippers R. Garcia, S. Logan, M. McPhee, J. Nookemus and the late T. Wenstob; A. Lawrence and C. Burger for assistance with the entry and analysis of data; and G. L. Hunt Jr. for valuable comments on an earlier draft.

\section{LITERATURE CITED}

Allen, SE, Vindeirinho C, Thomson RE, Foreman MGG, Mackas DL (2001) Physical and biological processes over a submarine canyon during an upwelling event. Can J Fish Aquat Sci 58:671-684

Anon. (2002) West Coast Offshore Vessel Traffic Risk Management Project. Final project report and recommenda- tions. Pacific States-British Columbia Oil Spill Task Force, Neskowin, OR. http://www.oilspilltaskforce.org/ wcovtrm_report.htm

Briggs KT, Tyler WB, Lewis DB, Carlson DR (1987) Bird communities at sea off California: 1975 to 1983. Stud Avian Biol 11:1-74

Burger AE (1991) Maximum diving depths and underwater foraging in alcids and penguins. In: Montevecchi WA, Gaston AJ (eds) Studies of high-latitude seabirds. 1. Behavioural, energetic and oceanographic aspects of seabird feeding ecology. Can Wildl Serv Occ Pap 68:9-15

Burger AE (1992) The effects of oil pollution on seabirds off the west coast of Vancouver Island. In: Vermeer K, Butler RW, Morgan KH (eds) The ecology, status and conservation of marine and shoreline birds of the west coast of Vancouver Island. Can Wildl Serv Occ Pap 75:120-128

Burger AE (1993a) Effects of the 'Nestucca' oil spill on seabirds along the coast of Vancouver Island in 1989. Can Wildl Serv Tech Rep Ser 179

Burger AE (1993b) Mortality of seabirds assessed from beached bird surveys in British Columbia. Can Field-Nat 107:164-176

Burger AE (2001) Diving depths of shearwaters. Auk 118: $755-759$

Burger AE (2003) Effects of the Juan de Fuca Eddy and upwelling on densities and distributions of seabirds off southwest Vancouver Island, British Columbia. Marine Ornith 31:113-122

Burger AE, Wilson RP, Garnier D, Wilson MPT (1993) Diving depths, diet, and underwater foraging of Rhinoceros Auklets in British Columbia. Can J Zool 71:2528-2540

Davoren GK (2000) Variability in foraging in response to changing prey distributions in rhinoceros auklets. Mar Ecol Prog Ser 198:283-291

Davoren GK, Burger AE (1999) Differences in prey selection and behaviour during self-feeding and chick provisioning in rhinoceros auklets. Anim Behav 58:853-863

Davoren GK, Montevecchi WA, Anderson JT (2002) Scaledependent associations of predators and prey: constraints imposed by flightlessness of common murres. Mar Ecol Prog Ser 245:259-272

Davoren GK, Montevecchi WA, Anderson JT (2003) Distribution patterns of a marine bird and its prey: habitat selection based on prey and conspecific behaviour. Mar Ecol Prog Ser 256:229-242

Denman KL, Mackas DL, Freeland HJ, Austin MJ, Hill SH (1981) Persistent upwelling and mesoscale zones of high productivity off the west coast of Vancouver Island, Canada. In: Richards FR (ed) Coastal Upwelling. Amer Geophys Union, Washington, DC, p 514-521

Fauchald P, Erikstad KE, Skarsfjord H (2000) Scaledependent predator-prey interactions: the hierarchical spatial distribution of seabirds and prey. Ecology 81: 773-783

Forbes ST, Nakken O (eds) (1972) Manual of methods for fisheries resource survey and appraisal. Part 2. The use of acoustic instruments for fish detection and abundance estimation. FAO Manuals Fisheries Sci No. 5. United Nations, Rome

Ford RG, Casey JL, Hewitt CH, Lewis DB, Varoujean DH, Warrick DR, Williams WA (1991) Seabird mortality resulting from the Nestucca oil spill incident, winter 1988-89. Rep Washington Dept Wildlife. Ecological Consulting, Portland, OR

Fulton J, LeBrasseur R (1984) Euphausiids on the continental shelf and slope of the Pacific coast of Canada. La Mer 22: $268-276$ 
Götmark F, Winkler DW, Andersson M (1986) Flock-feeding on fish schools increases individual success in gulls. Nature 319:589-591

Haney JC (1989) Remote characterization of marine bird habitats with satellite imagery. Colon Waterbirds 12: 67-77

Hay DE, Healey MC, Ware DM, Wilimovsky NJ (1992) Distribution, abundance and habitat of prey fish on the west coast of Vancouver Island. In: Vermeer $\mathrm{K}$, Butler RW, Morgan KH (eds) The ecology, status and conservation of marine and shoreline birds of the west coast of Vancouver Island. Can Wildl Serv Occ Pap 75:22-29

Hay RB (1992) The oceanic habitats of seabirds: their zonal distribution off Vancouver Island, British Columbia, Canada. J Biogeog 19:67-85

Hoffman WD, Heinemann D, Wiens JA (1981) The ecology of seabird feeding flocks in Alaska. Auk 98:437-456

Hunt GL Jr (1997) Physics, zooplankton, and the distribution of least auklets in the Bering Sea - a review. ICES J Mar Sci 54:600-607

Hunt GL Jr, Schneider DC (1987) Scale-dependent processes in the physical and biological environment of marine birds. In: Croxall JP (ed) Seabirds: feeding ecology and role in marine ecosystems. Cambridge University Press, Cambridge, p 7-41

Hunt GL Jr, Coyle KO, Hoffman S, Decker MB, Flint EN (1996) Foraging ecology of short-tailed shearwaters near the Pribilof Islands, Bering Sea. Mar Ecol Prog Ser 141: $1-11$

Hunt GL Jr, Mehlum F, Russell RW, Irons D, Decker MB, Becker PH (1999) Physical processes, prey abundance, and the foraging ecology of seabirds. In: Adams NJ, Slotow RH (eds) Proc 22nd Intern Ornith Congr (CDROM). BirdLife South Africa, Johannesburg, p 2040-2056

Logerwell EA, Hargreaves NB (1996) The distribution of sea birds relative to their fish prey off Vancouver Island: opposing results at large and small spatial scales. Fish Oceanogr 5:163-175

Logerwell EA, Hewitt RP, Demer DA (1998) Scale-dependent spatial variance patterns and correlations of seabirds and prey in the southeastern Bering Sea as revealed by spectral analysis. Ecography 21:212-223

Mackas DL (1992) Seasonal cycle of zooplankton off southwestern British Columbia: 1979-1989. Can J Fish Aquat Sci 49:903-921

Mackas DL, Galbraith M (1992) Zooplankton on the west coast of Vancouver Island: distribution and availability to marine birds. In: Vermeer K, Butler RW, Morgan KH (eds) The ecology, status and conservation of marine and shoreline birds of the west coast of Vancouver Island. Can Wildl Serv Occ Pap 75:15-21

Mackas DL, Kieser R, Saunders M, Yelland DR, Brown RM, Moore DF (1997) Aggregation of euphausiids and Pacific hake (Merluccius productus) along the outer continental shelf off Vancouver Island. Can J Fish Aquat Sci 54: 2080-2096

Maniscalco JM, Ostrand WD, Suryan RM, Irons DB (2001) Passive interference competition by glaucous-winged gulls on black-legged kittiwakes: a cost of feeding in flocks. Condor 103:616-619

Martin PW, Myres MT (1969) Observations on the distribution and migration of some seabirds off the outer coasts of British Columbia and Washington State, 1946-1949. Syesis 2:241-256

Mehlum FG, Hunt GL Jr, Klusek Z, Decker MB (1999) Scaledependent correlations between the abundance of
Brünnich's guillemots and their prey. J Anim Ecol 68: $60-72$

Montevecchi WA (2002) Interactions between fisheries and seabirds. In: Schreiber EA, Burger J (eds) Biology of marine birds. CRC Press, Boca Raton, FL, p 527-557

Morgan KH, Vermeer K, McKelvey RW (1991) Atlas of pelagic birds of Western Canada. Can Wildl Serv Occ Pap 72

O'Driscoll RL (1998) Description of spatial pattern in seabird distributions along line transects using neighbour K statistics. Mar Ecol Prog Ser 165:81-94

O'Driscoll RL, Schneider DC, Rose GA, Lilly GR (2000) Potential contact statistics for measuring scale-dependent spatial pattern and association: an example of northern cod (Gadus morhua) and capelin (Mallotus villosus). Can J Fish Aquat Sci 57:1355-1368

Parrish JK, Lemberg N, South-Oryshchyn L (1998) Effects of colony location and nekton abundance on the at-sea distribution of four seabird species. Fish Oceanogr 7:126-135

Piatt JF (1990) The aggregative response of common murres and Atlantic puffins to schools of capelin. Studies Avian Biol 14:36-51

Pielou EC (1969) An introduction to mathematical ecology. Wiley-Interscience, New York

Porter JM, Sealy SG (1981) Dynamics of seabird multispecies feeding flocks: chronology of flocking in Barkley Sound, British Columbia, in 1979. Colon Waterbirds 4:104-113

Schneider DC (2002) Scaling theory: application to marine ornithology. Ecosystems 5:736-748

Schneider DC, Piatt JF (1986) Scale-dependent correlation of seabirds with schooling fish in a coastal ecosystem. Mar Ecol Prog Ser 32:237-246

Sealy SG (1973) Interspecific feeding assemblages of marine birds off British Columbia. Auk 90:796-802

Tasker ML, Hope-Jones P, Dixon T, Blake BF (1984) Counting seabirds at sea from ships: a review of methods employed and a suggestion for a standardized approach. Auk 101: $567-577$

Van Franeker JA (1994) A comparison of methods for counting seabirds at sea in the southern ocean. J Field Ornith 65:96-108

Vermeer K, Butler RW, Morgan KH (eds) (1992) The ecology, status, and conservation of marine and shoreline birds on the west coast of Vancouver Island. Can Wildl Serv Occ Pap 75

Vermeer K, Morgan KH, Smith GEJ, Hay R (1989) Fall distribution of pelagic birds over the shelf off SW Vancouver Island. Colon Waterbirds 12:207-214

Vermeer K, Sealy SG, Sanger GA (1987) Feeding ecology of Alcidae in the eastern North Pacific Ocean. In: Croxall JP (ed) Seabirds: feeding ecology and role in marine ecosystems. Cambridge Univ. Press, Cambridge, p 189-227

Vlietstra LS (in press) Spatial associations between seabirds and prey: effects of large-scale prey abundance on smallscale seabird distribution. Mar Ecol Prog Ser

Wahl TR, Morgan KH, Vermeer K (1993) Seabird distribution off British Columbia and Washington. In: Vermeer $\mathrm{K}$, Briggs KT, Morgan K, Siegel-Causey, D (eds) The status, ecology and conservation of marine birds of the North Pacific. Can Wildl Serv Spec Publ, Ottawa, p 39-47

Wiens JA, Ford RG, Heinemann D (1984) Information needs and priorities for assessing the sensitivity of marine birds to oil spills. Biol Conserv 28:21-49

Wittenberger JF, Hunt GL Jr (1985) The adaptive significance of coloniality in birds. In: Farner DS, King JR, Parkes KC (eds) Avian Biology, Vol. 8. Academic Press, Orlando, FL, p $1-79$ 